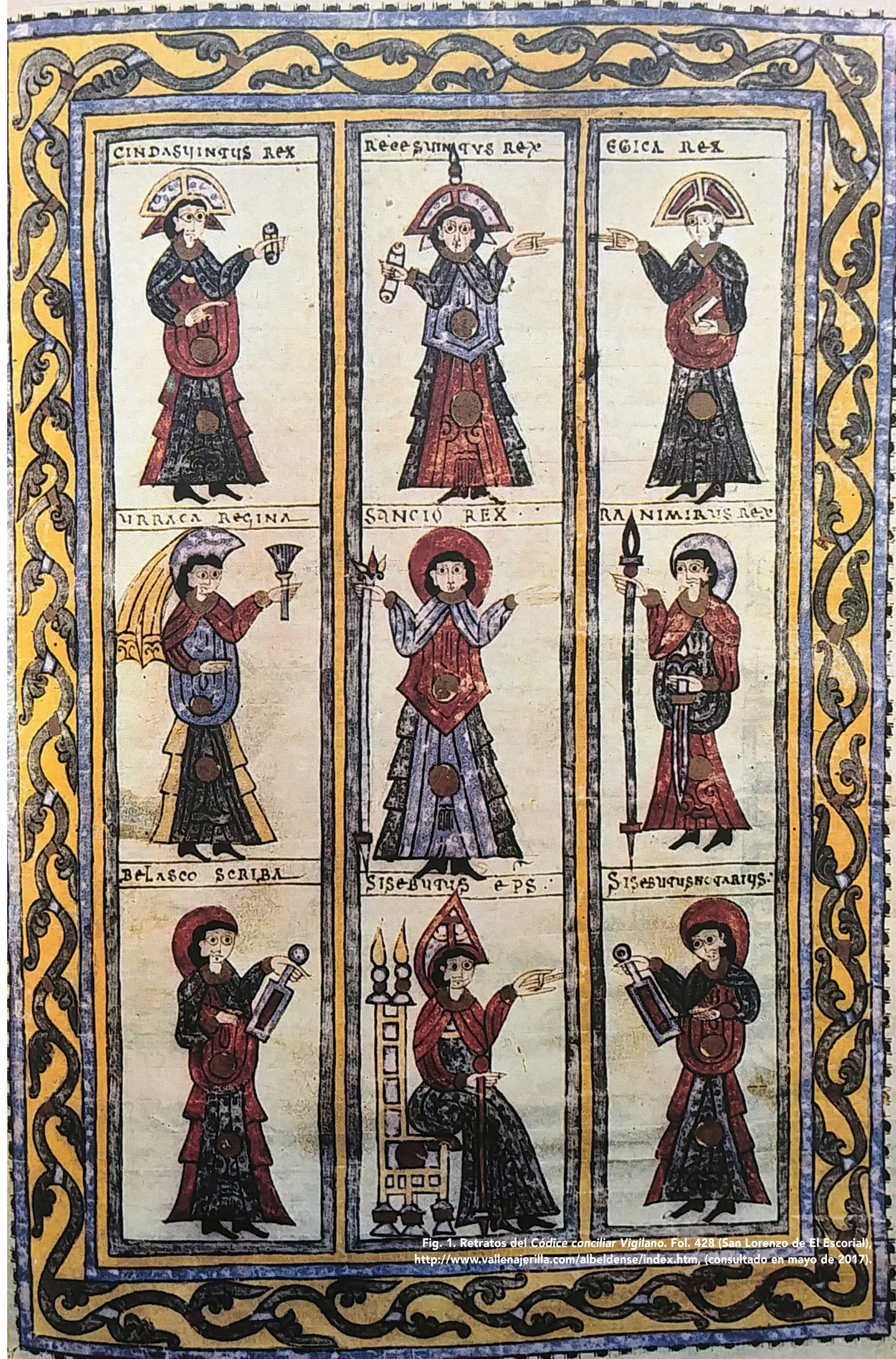




\section{Los orígenes riojanos del "Rubí" del Príncipe Negro: una relectura iconográfica de los códices de San Millán y Vigilano o Albeldense}

The Riojano origins of the Black Prince Ruby.

A new iconographic reading of the codices of San Millán and Vigilano or Albeldense

\section{Fernando Rubert Vericat}

Anticuario, Nueva York, Estados Unidos

rubertfernando09@gmail.com

https://orcid.org/0000-0001-8921-6980

\section{Resumen}

Una de las joyas históricas mejor documentadas del tesoro de la corona británica es el llamado "rubí del Príncipe Negro" que adorna en una posición frontal privilegiada la Corona Imperial del Estado. Recibe este nombre por su primer propietario inglés, Eduardo de Woodstock (1330-1376), más conocido como el Príncipe Negro, y está vinculado con su victoria en la batalla de Nájera el 3 de abril de 1367, hace 650 años. Ante la aceptación reciente de la hipótesis poco fundada que defiende el origen Nazarí de esta enorme espinela, supuestamente arrebatada por Pedro de Castilla al rey Bermejo, este artículo documenta la presencia de esta joya en La Rioja, en fechas tan tem-

\begin{abstract}
The "Black Prince's Ruby" is one of the most famous historical gems of the British Royal Treasure. It is an enormous spinel which adorns the Imperial Crown of the State in a privileged frontal position. It is named after its first English owner, Edward de Woodstock (1330-1376), better known as the Black Prince, and is linked to his victory at the Battle of Najera on April 3, 1367, 650 years ago. The hypothesis of his first historical record in the hands of a Nazari king of Granada killed by Pedro of Castille is ill-founded but commonly accepted nowadays. This article demonstrates that there are historical reasons for thinking that the spinel can be documented long before in La Rioja, as early as the tenth century.
\end{abstract}

Cómo citar este trabajo / How to cite this paper:

RUBERT VERICAT, Fernando, "Los orígenes riojanos del "Rubí" del Príncipe Negro: una relectura iconográfica de los códices de San Millán y Vigilano o Albelden$\mathrm{se}^{\prime \prime}$, Atrio. Revista de Historia del Arte, n. ${ }^{\circ} 24,2018$, págs. 10-31.

Copyright (c) 2018 Fernando Rubert Vericat. Este es un artículo de acceso abierto distribuido bajo los términos de la licencia Creative Commons AttributionNonCommercial-ShareAlike 4.0. International License (CC BY-NC-SA 4.0). 
pranas como el siglo X. Se aportan tanto las pruebas históricas tradicionales que vinculaban a esta simbólica gema con Santa María la Real de Nájera, como nuevos descubrimientos basados en ilustraciones conocidas pero mal interpretadas de la Maiestas Domini de los códices Albeldense y Emilianense.

Palabras clave: Rubí; espinela; Codice Vigilano; Príncipe Negro; Corona Imperial del Estado; Santa María la Real de Nájera; iconografía; Maiestas Domini.
First, following the record of the lost Cartulario of Santa Maria la Real de Nájera, as it was studied by prominent witness; second, with new discoveries based on wellknown but misinterpreted illustrations of the Maiestas Domini of the Albeldense and Vigilano codices.

Keywords: Ruby-spinel; Codice Vigilano; Black Princés Ruby; Santa Maria la Real de Nájera; RiojaGranada; Miestas Domini's iconography.

Introducción Una de las joyas históricas mejor documentadas del tesoro de la corona británica es el llamado "rubí del Príncipe Negro" que adorna en una posición frontal privilegiada la Corona Imperial del Estado (Fig. 2). Recibe este nombre por su primer propietario inglés, Eduardo de Woodstock (1330-1376), más conocido como el Príncipe Negro. Era hijo del rey Eduardo III y heredero a la corona como Príncipe de Gales, pero nunca llegaría a reinar, porque murió joven por causa de una enfermedad adquirida durante su viaje a Espańa en 1366-67. El sobrenombre negro le viene del color de su armadura y la fama legendaria que le acompañaba como estratega invencible e implacable. Históricamente, se trata de una gema asociada con la batalla de Nájera, última gran victoria de este caballero inglés, que tuvo lugar el 3 de abril de 1367. El 650 aniversario puede ser un buen momento para aportar información sobre los orígenes de una de las piedras preciosas con más pedigrí.

En los estudios canónicos sobre las joyas de la corona británica hay unanimidad en afirmar que fue un regalo, o parte del pago por su ayuda militar, que le hizo el rey Pedro de Castilla, conocido como el Cruel, con ocasión de esta última gran victoria del Príncipe Negro en España ${ }^{1}$. Gracias al apoyo de las fuerzas armadas anglo-gasconas del Príncipe, que era también señor de la Guyena-Aquitania, Pedro I venció a su hermanastro Enrique de Trastámara, y mantuvo su trono dos años más, aunque finalmente sería vencido y asesinado por Enrique en Montiel.

Esta información histórica oficial sirvió para justificar que la joya del Príncipe Negro podía provenir del ajuar de la Virgen titular del Monasterio de Santa María la Real, como es narrado en las crónicas populares que desde hace 50 años se representan en esta localidad de Nájera. Otras versiones afirman que podría estar en San Millán de la Cogolla, que fue saqueado, como el monasterio de San Salvador de Oña, por las tropas del Príncipe Negro, pero estas carecen de fundamento científico serio, salvo por la mención de un llamativo carbunco (sic.) que se escondía dentro del arca con los restos de San Millán, y que es mencionado en la historia general de la orden de San Benito del padre Yepes².

Las que afirman que provenía de Nájera se apoyan en el testimonio del erudito najerino Constantino Garrán que tuvo acceso a un tomo del Becerro de santa María la Real que se encontraba en Bilbao, en

1. Cf. por ejemplo el más reciente trabajo de STRATFORD, Jenny, Richard II and the English Royal Treasure, Suffolk, Boydell Press, 2012

2. YEPES, Antonio de, Coronica general de la orden de San Benito, Volumen 7, 1621, pág. 81. 


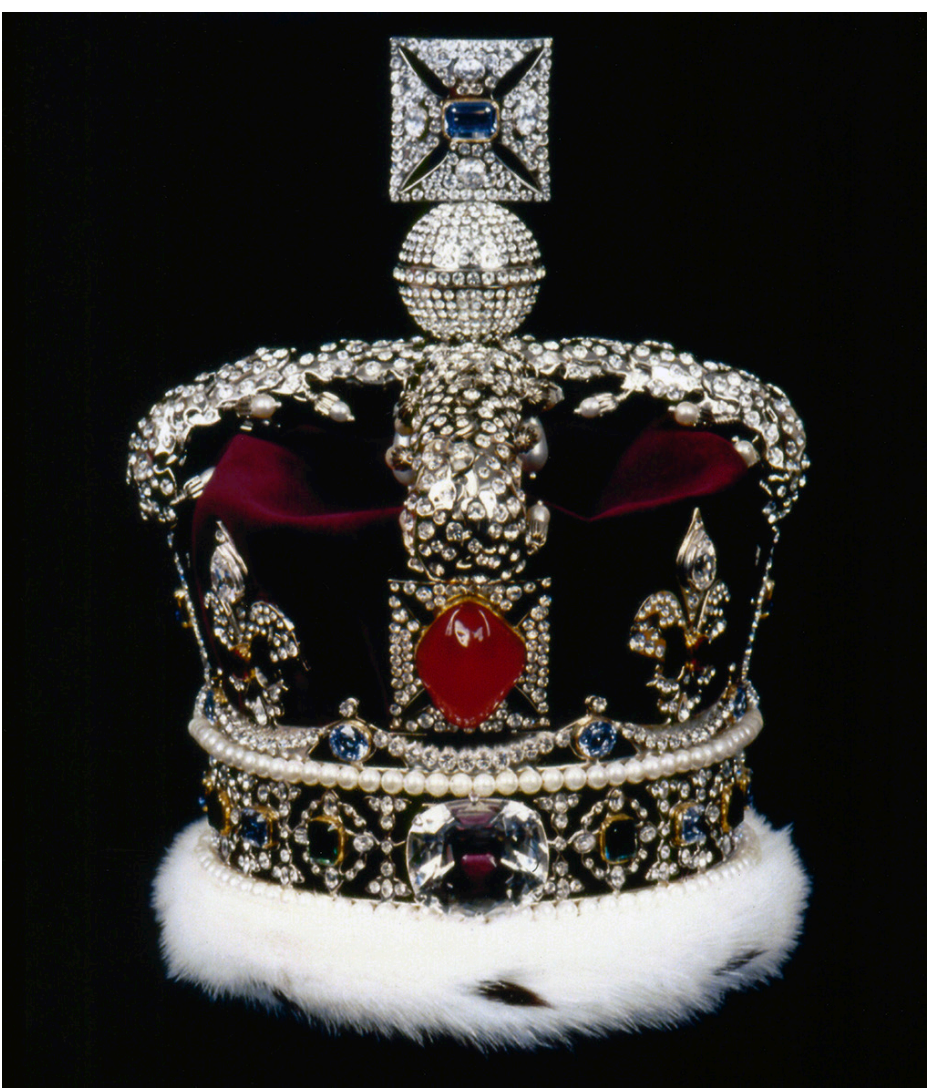

Fig. 2. Corona Imperial del Estado Británico con el rubí del Príncipe Negro, (u. commons).

propiedad del minero y armador bilbaíno Luis de Ocharán. En él figuraba detallado el inventario del tesoro; en concreto, en la entrada del 2 de mayo de la Era 1372 (que es el año de Cristo 1334) se describe el rico ajuar perteneciente a la imagen de Santa María la Real, titular del monasterio. También figura una relación de las alhajas que arrebató el Rey Don Pedro I de Castilla al monasterio, y en cuya reclamación, evaluada en treinta mil doblas de oro castellana, suscriben en diligencia personajes ilustres del momento, obispos, jueces, etc. Está fechada esta relación el día 11 de noviembre de la Era 1417 (que es el año de Cristo 1379) ${ }^{3}$.

Por la desaparición de este libro Becerro, que le fue sustraído a Luis de Ocharán de su casa en Castro Urdiales durante la Guerra Civil y sigue en paradero desconocido, no se conservan más pruebas documentales que vinculen al rubí con la batalla de Nájera que ese testimonio de Constantino Garrán, que incluye la referencia al que Fidel Fita descubrió en el Archivo Histórico Nacional ${ }^{4}$. Esta investigación confirmaba la opinión del padre Moret, que en sus Antigüedades del reino de Navarra concluye que el famoso carbunclo de la Cruz de Sancho Abarca, cuyo tamaño y brillantez era tal que podía iluminar en la oscuridad, desapareció después de la Batalla de Nájera5.

Es importante volver a recordar esta tradición histórica puesto que está generalizándose en el imaginario popular la hipótesis de la proveniencia granadina de este rubí. Según esta teoría, ya aceptada en las explicaciones divulgativas sobre la historia del "rubí" Príncipe $\mathrm{Negro}^{6}$, el "rubí" le fue entregado al Príncipe Negro en Bayona antes de la Batalla de Nájera, como adelanto por los servicios militares que iba a prestarle para recuperar el trono de Castilla. Pero no hay más pruebas documentales al respecto que varias referencias a

\footnotetext{
3. GARRÁN, Constantino, "El Becerro de Santa María la Real de Nájera", Boletín de la Real Academia de la Historia, Tomo 49, 1906, págs. $385-389$.

4. Merece también la pena citar los estudios del Cartulario completo de Nájera publicados por Julián Cantera Orive, Cf. Un cartulario de Santa María la Real de Nájera del año 1209, Biblioteca Gonzalo de Berceo, n. ${ }^{\circ}$ 55, págs. 331-346, http://www.vallenajerilla.com/berceo/canteraorive/cartulariosantamarialarealdenajera.htm, (consultado en mayo de 2017).

5. MORET, José, Investigaciones Historicas De Las Antiguedades Del Reyno De Navarra, Por El Padre Joseph De Moret, De La Compañía De Jesús, 6, 1766 (tercera ed.). Cap. VIII, págs. 448-49. Esta información es recogida en ARRUE UGARTE, Begoña, "Cruces procesionales en La Rioja: aspectos tipológicos, siglos XIII al XVI", Cuadernos de Investigación Histórica, Brocar, n. ${ }^{\circ} 14,1988$, cita 9, pág. 124.

6. https://www.royalcollection.org.uk/collection/31701/the-imperial-state-crown, (consultado en mayo de 2017).
} 
balajes o espinelas que aparecen en las crónicas del Canciller Ayala ${ }^{7}$. Y sin embargo, pese a su falta de seriedad científica, es una teoría que también aceptan expertos joyeros y de antigüedades. Por eso la pertinencia del estudio histórico que proponemos a continuación.

\section{Los nombres del carbúnculo o carbunclo: ¿rubí, balaj o espinela?}

La denominación Carbunclo hace referencia a una piedra preciosa de color rojo intenso, normalmente el rubí. La etimología de los balajes que menciona el canciller Ayala procede de árabe "balahs", reducción de la voz "balahsi", gentilicio de Badahs(ān), palabra que remite a la región de Badkhshan, en Asia Central, de donde proceden este tipo de piedras semipreciosas. El nombre espinela, más generalizado actualmente, lo recibió el mineral en el siglo XVI en la obra De Re Metallicae de Georgius Agrícola, todavía no sabemos la razón, aunque la hipótesis más aceptada es que fue tomado el nombre del latín "spina", en alusión a la corona de Cristo, por sus formas alargadas y rojizas, como la sangre que impregnaba estas reliquias ${ }^{8}$.

La teoría sobre los orígenes nazaríes del Príncipe Negro se basa fundamentalmente en el hecho de que la gema sea un balaj o espinela. Contra esta hipótesis puede aducirse, en primer lugar, que no es posible que lo que ya se diferenciaba en la época del Príncipe Negro, pues Ayala habla de piedras balaj y no de rubíes, no se tuviera en cuenta en los documentos de época relacionados con el rubí del Príncipe Negro. Si los castellanos sabían que los del rey Bermejo eran balajes o espinelas, también los ingleses tendrían que saberlo. Pero sólo muy recientemente se ha hecho público que el Príncipe Negro es una espinela y no un rubí, tal es su calidad y presencia. En segundo lugar, no tiene sentido que el Príncipe Negro guardara consigo esta joya como un tesoro muy particular hasta su muerte en 1376, dejándola en donación para su hijo, futuro rey Ricardo II, nacido en Burdeos tres meses antes de la batalla de Nájera, si no hubiera sido una gema de excepcional valor simbólico, y no una más entre las muchas del botín.

Los estudios sobre las Joyas de la Corona Británica custodiadas en la Torre de Londres hacen del rubí del Príncipe Negro un talismán de legendarios poderes, vinculado con múltiples cambios dinásticos. La relación de sus avatares históricos excede el espacio de este estudio, por lo que nos limitaremos a mencionar que en 1838 fue colocado en el centro de la Corona Imperial del Estado, que se forjó para celebrar la solemne coronación de la Reina Victoria. Esta corona Imperial fue rehecha para la coronación de Jorge VI en 1937 por la compañía de joyeros Garrard \& Co, y modificada después para ajustarla al estilo de la reina Isabel en su coronación de 1953, para lo que se rebajaron los arcos $25 \mathrm{~mm}$. y se le dio una apariencia más femenina ${ }^{10}$. En esas fechas más tardías ya se sabía que el Príncipe Negro no era un rubí, pero por su belleza y la leyenda que le acompañaba se mantuvo haciendo grupo al lado de un diamante como la Estrella de África (Cullinan II) y el zafiro de San Eduardo, además de auténticos diamantes, esmeraldas y perlas, algunas de ellas pertenecientes a Isabel I.

Es la gema más llamativa en tamaño y esplendor: 170 quilates, 34 gramos y 5,08 centímetros en su

\footnotetext{
7. "Y luego que el rey Bermejo fue preso, fue catado (registrado) aparte, (por) si tenía algunas joyas consigo, y halláronle tres piedras balajes, muy nobles y muy grandes". LÓPEZ DE AYALA, Pedro, Crónica del rey don Pedro, año III, 1362, cap. V. en Imprenta de don Antonio de Sancha, Crónicas de los reyes Castilla, I: Crónica del rey don Pedro, Madrid, 1779, pág. 347.

8. SOLANS HUGUET, Joaquín, Gemas de ayer, de hoy y de mañana. Introducción al Estudio de las piedras preciosas, Barcelona, Edicions Universitat Barcelona, 1914, pág. 55.

9. BUTLER, Thomas, The Crown Jewels and Coronation Ceremony, Pitkin, Antiques \& Collectibles, 1989, pág. 6.

10. KEAY, Anna, The Crown Jewels: The Official Illustrated History, London, Thames \& Hudson. 2011, pág. 183.
} 
diámetro más ancho. Tiene forma irregular, y está sin tallar, nada más que ligeramente pulido. Estaba perforado para servir como colgante, y actualmente lleva un pequeño rubí incrustado en ese orificio. Esta forma de llevarlo no necesariamente es algo oriental, que lo vincule al mundo islámico, como argumentan los defensores de la teoría granadina. Está documentado que Enrique VIII lo llevaba así, como collar, y quizás fue en esta época cuando se hizo la perforación. Pero el Príncipe Negro lo lucía en el sombrero, e inmediatamente después se describe adornando los yelmos coronados, tanto de Enrique $\mathrm{V}$ en la famosa batalla de Agincourt como de Ricardo III, el último Plantagenet, en la de Bosworth. Solo posteriormente, ya en la época Tudor y Estuardo, el supuesto rubí se usó como colgante ${ }^{11}$.

\section{Santa María la Real de Nájera en la encrucijada}

La tradición riojana siempre ha privilegiado la cualidad simbólica de la gema, que la convierte en un unicum, además de una gema con valor monetario. Aunque su origen fuera musulmán, no era de procedencia Nazarí, sino muy anterior. Se ha especulado incluso sobre su relación con la Mesa de Salomón que se disputaron Muza y Tarik, pero no hay datos verificables más allá de las referencias a esta disputa en las crónicas árabes. Las primeras notas históricas fiables se encuentran en las crónicas sobre el reino de Navarra, y hacen referencia a las piedras preciosas que decoraban la Cruz de Sancho II Abarca, realizada en el último cuarto del siglo X.

Este rey de Pamplona hizo de Nájera la segunda sede de su reino y privilegió a La Rioja como lugar de asentamiento de monasterios muy importantes para la historia de Espańa y Europa, como San Millán de la Cogolla o San Martín de Albelda. Con el apoyo a estos monasterios situados en una zona de encrucijada cultural entre Castilla, Aragón y Navarra (o mejor dicho, del reino Pamplona-Nájera, pues la denominación Navarra no aparece hasta el siglo XII), los reyes de la dinastía de Pamplona buscaban, en primer lugar, ampliar su ámbito de influencia; y sobre todo, legitimar su poder tanto en la recuperación del Imperio de Occidente llevada a cabo por Carlomagno como en las tradiciones visigóticas anteriores a la Reconquista y al imperio carolingio.

Todo esto puede verse en el famoso Códice Vigilano o Albeldense, firmado por el escriba Vigila en el año 976, pero que recoge crónicas alfonsinas que se remontan al año 881. Sería por tanto la más antigua de las crónicas que hacen referencia a la monarquía asturiana, a la que el códice vincula con la tradición visigótica anterior y también con los monarcas de Pamplona-Nájera ${ }^{12}$. Sancho, su esposa Urraca Fernández, hija del famoso conde de Castilla Fernán González, aparecen retratados junto a su hermano Ramiro, rey de Viguera, en el más antiguo ejemplo áulico de los reinos hispánicos. También se retratan los comitentes y escribas, y los reyes legisladores visigodos Recesvinto, Chindasvinto y Égica (Fig. 1). No es casual esta

11. ORPEN, Goddard, Stories about Famous Precious Stones, Boston, Lothrop, 1890, págs. 152-153.

12. El nombre de Albeldense le viene del códice del lugar donde se encontraba el monasterio de San Martín, Albelda de Iregua, La Rioja. Fue fundado por Sancho I de Pamplona en el año 924, un año después de conquistar Nájera junto con el rey de Asturias-León Ordoño II. Pero el gran promotor de este monasterio y del Códice Albeldense o Vigilano (Codex Conciliorum Albeldensis seu Vigilanus), fue su nieto Sancho II Abarca. Gracias a este rey, en una época de hierro que coincide con las destrucciones de las capitales Pamplona, Santiago, León y Barcelona por Almanzor, los monasterios de La Rioja se convirtieron en la referencia cultural más significativa de la Hispania cristiana. GIL FERNÁNDEZ, Juan; MORALEJO, José Luis y RUIZ DE LA PEÑA SOLAR, Juan Ignacio, Crónicas asturianas, Oviedo, Universidad de Oviedo (Publicaciones del Departamento de Historia Medieval, 11), 1985. Cf. también, ISLA FREZ, Amancio, "Identidades y goticismo en época de Alfonso III: las propuestas de la Albeldense", Territorio, Sociedad y Poder, n. ${ }^{\circ}$, 2011, págs. 11-21, http://www.unioviedo.es/reunido/index.php/ TSP/article/viewFile/9466/9279 (consultado en mayo de 2017). 
selección, puesto que el códice supone la primera compilación canónica de Europa, en continuidad con la tradición hispánica anterior a la conquista, en un momento histórico en que las leyes de la Iglesia eran también de aplicación civil ${ }^{13}$.

Trataremos más adelante sobre las ilustraciones de este códice. Sirvan de momento estas notas históricas para recordar que los herederos de Sancho II Abarca hicieron de Nájera una de las capitales más importantes de la España cristiana en los siglos X y XI. El rey Sancho III el Mayor (1005-1035) de PamplonaNájera dejó en herencia para sus hijos Fernando, Ramiro y García los tres grandes reinos que se disputaron la reconquista. García III, conocido como el de Nájera, heredó la corona de Pamplona, por ser el primogénito de Sancho el Mayor. Sus hermanos Fernando y Ramiro gobernaban como condes de Castilla y Aragón respectivamente, y solo por su posterior vinculación a los reinos de León y Pamplona legitimaron el título de reyes para sus respectivos territorios, aprovechando la muerte de García el de Nájera en la batalla de Atapuerca (1054). El causante de esta desgracia, su hermano Fernando, tuteló la minoría de Sancho IV de Pamplona, e invirtió los vasallajes, haciendo de Castilla-León el reino principal.

Pero antes de que esto ocurriera, García III de Nájera-Pamplona fundó el Monasterio de Santa María la Real, llamado así porque era también palacio del monarca y, con el tiempo, uno de los mausoleos más importantes de los reyes de Navarra. Hasta comienzos del siglo XX se conservaba la carta de fundación y donación (1044), una verdadera maravilla de la miniatura. Tal como la describe Sandoval, el rey García y la reina Estefanía se situaban lujosamente vestidos a ambos lados de una maqueta de la iglesia con arcos de herradura ${ }^{14}$, en una actitud muy similar a la realizada posteriormente para el libro de horas de Fernando de Castilla y León, que se considera el primer retrato áulico para conmemorar un momento histórico (Fig. 3), por desconocimiento de sus precedentes riojanos.

Actualmente en paradero desconocido, han llegado hasta nosotros, aunque en mal estado, dos copias inmediatamente posteriores de esta carta de donación encargadas por su viuda y su hijo para confirmar la primera ${ }^{15}$. Contamos también con una crónica, la Najerense, bastante fidedigna por su proximidad a los hechos, aunque escrita ya en clave anti-navarra, cuando Nájera había sido incorporada a Castilla-León por el rey Alfonso VI, y los clérigos agustinos originales del monasterio habían sido sustituidos por cluniacenses, que son los monjes que la escriben ${ }^{16}$.

Con estos documentos fundacionales y crónicas minuciosas, la investigadora Cantera Montenegro ha estudiado en profundidad la historia del Monasterio de Santa María la Real, y también sus leyendas re-

13. SILVA Y VERÁSTEGUI, Soledad de, "Los primeros retratos reales en la miniatura hispánica altomedieval. Los monarcas de Pamplona y de Viguera", Príncipe de Viana, Pamplona, 1980, págs. 160-161.

14. SANDOVAL, Prudencio de, Primera parte de las fundaciones de los monasterios del glorioso Padre San Benito ... y de los santos ... varones desta sagrada religion, que desde el año DXL ... hasta el año DCCXIIII ... han florecido en estos monasterios ... Publicación original: En Madrid, por Luis Sánchez, 1601. Cit. en SILVA Y VERÁSTEGUI, Soledad de, "La miniatura en el Reino de Pamplona-Nájera (905-1076)", IGLESIA, José Ignacio de la (coord.), García Sánchez III "el de Nájera" un rey y un reino en la Europa del siglo XI: XV Semana de Estudios Medievales, Nájera, Tricio y San Millán de la Cogolla, Logroño, Instituto de Estudios Riojanos, 2005, págs. 327-366.

15. Este documento fue confirmado por su esposa Estefanía de Foix en 1054 y por su hijo Sancho el de Peñalén en 1056, y estas confirmaciones sí que pueden verse en la Biblioteca de la Real Academia de la Historia y en los archivos de la catedral de Calahorra. Describen las miniaturas y los textos de este documento cuando todavía se conservaba. SANDOVAL, Prudencio de, Primera parte de las fundaciones de los monasterios del glorioso Padre San Benito ..., op. cit., fols. 51 y 52; FITA, Fidel, "Santa María la Real de Nájera. Estudio Crítico", Boletín de la Real Academia de la Historia, 1885, págs. 155 y ss.

16. Cf. REGLERO DE LA FUENTE, Carlos M., La Crónica najerense, Santa María de Nájera y Cluny, en E-Spania, 2009, http://e-spania.revues.org/18162, (consultado en mayo de 2017). 


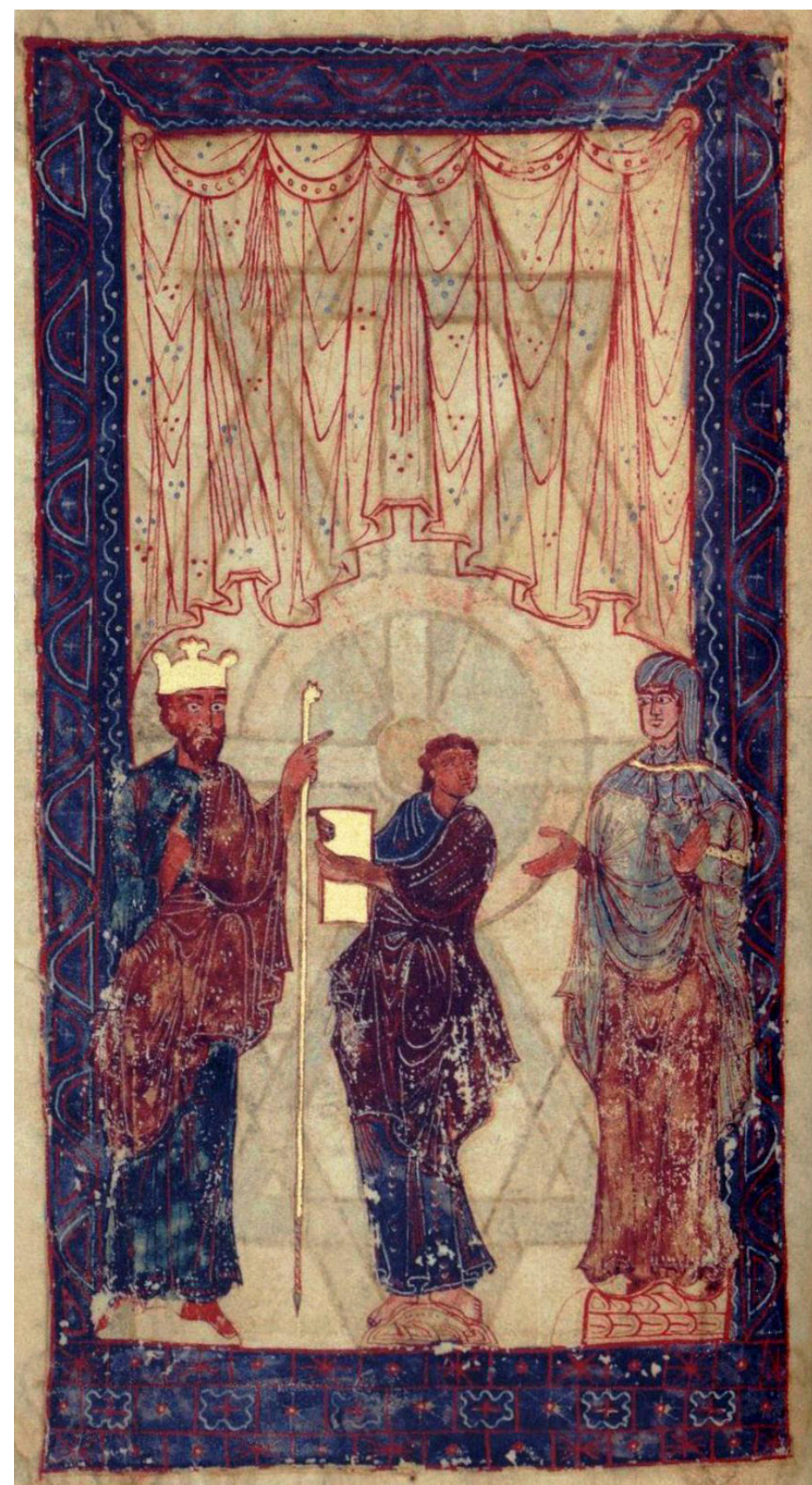

Fig. 3. Libro de horas de Fernando I San Isidoro de Léon, 1055, los reyes recibiendo el códice de manos de su autor (folio 3v). Biblioteca Xeral Universitaria, Santiago de Compostela, Ms. 609 (Res. 1).

https://www.pinterest.es/pin/572660908845303616/?|p=true, (consultado en mayo de 2017). lacionadas con el hallazgo por el rey Don García de la imagen de la Virgen en una cueva mientras cazaba con halcón ${ }^{17}$. A la aparición de la imagen atribuyó don García la conquista de Calahorra, antigua diócesis de la zona; y quiso agradecerlo con el monasterio dedicado a Santa María. Las reminiscencias con la Virgen de Covadonga encontrada también en una cueva en relación con una decisiva batalla contra los musulmanes no son casuales. Se trataba de justificar con unos orígenes ancestrales y milagrosos la devoción a la imagen románica del siglo XI, que es cuando el culto a las imágenes de bulto se hace universal. Por eso en la carta de fundación del monarca, fechada el 12 de noviembre de 1052 no se alude a esta leyenda fundacional. Solo se recoge que el rey ha decidido construir la iglesia y monasterio para honrar a la Madre de Dios, para que viva en él una comunidad de clérigos y para remedio de su alma ${ }^{18}$.

El rey García quiso privilegiar tanto al nuevo monasterio que puso en él su corte, futuro mausoleo, y una sede episcopal. Al no poder mantener en Nájera la sede calagurritana, ya recuperada, trasladó a Nájera la cátedra castellana de Valpuesta, por lo que entró en conflicto con su hermano Fernando el Magno, ya investido rey de

17. CANTERA MONTENEGRO, Margarita, Santa María la Real de Nájera. Siglos XI-XIV, T. I -de 3- Madrid, Universidad Complutense, 1987, pág. 78 y "La devoción mariana en La Rioja medieval", VV.AA., Devoción mariana y sociedad medieval, actas del simposio, Ciudad Real, Instituto de Estudios Manchegos, 1990, pág. 456. Cf. también de la misma autora, "Santa María la Real de Nájera en la Edad Media", I Semana de Estudios Medievales, Nájera, del 6 al 11 de agosto de 1990, Logroño, Instituto de Estudios Riojanos, 2001, págs. 207-230. https://dialnet.unirioja.es/descarga/articulo/595370.pdf (consultado en mayo de 2017).

18. Describen las miniaturas y los textos de este documento cuando todavía se conservaba: SANDOVAL, Prudencio de, Catálogo de los obispos que ha tenido la Santa Iglesia de Pamplona, Pamplona, 1614, fols. Págs. 51 y 52; FITA, Fidel, "Santa María la Real de Nájera. Estudio Crítico", op. cit. Este documento fue confirmado por su esposa Estefanía de Foix en 1054 y por su hijo Sancho el de Peñalén en 1056, y estas confirmaciones sí que pueden verse en la Biblioteca de la Real Academia de la Historia y en los archivos de la catedral de Calahorra. 
León y Castilla. El 1 de septiembre de 1054 perdía la vida en la batalla de Atapuerca. Todavía hoy, aunque ya sin derramamiento de sangre, perviven estas discusiones fronterizas, porque es en Valpuesta donde se han encontrado algunos escritos que se consideran primeros antecedentes del castellano. Las famosas glosas emilianenses, que se escriben posiblemente en el Monasterio de Yuso, fundado, como el de Nájera, por el rey García, serían según los expertos de Castilla un dialecto navarro-aragonés y no castellano ${ }^{19}$.

Con esta comparativa actual sobre hechos aparentemente lejanos, nos interesa sobre todo ilustrar cómo las crónicas reescriben siempre la historia de los orígenes, y por su posición de encrucijada entre $\mathrm{Na}$ varra y Castilla, Nájera tuvo la mala fortuna de pasar de ser deseada por todos a quedar olvidada, por no pertenecer finalmente a ninguna de estas dos comunidades de fuerte personalidad histórica. La Comunidad Autónoma de La Rioja es muy reciente, y también lo es su universidad. Y es tal el olvido del patrimonio riojano tanto a nivel político como académico que es necesario volver a recordar los orígenes riojanos del Rubí del Príncipe Negro.

\section{La prehistoria riojana del Príncipe Negro}

La dotación de ajuar litúrgico que hizo García el de Nájera a su fundación no pudo ser más espléndida, gracias al botín tomado en la recién conquistada Calahorra y a las parias que recibía de la taifa de Zaragoza. Los testimonios del padre Yepes, quien a su vez se apoya en los de Sandoval (ambos testigos de vista de lo que describen) confirman lo que dicen los documentos de donación: que "Derramó el rey García las alhajas con franca mano sin perdonar las más ricas piezas de su oratorio y de los Reyes sus antepasados" ${ }^{20}$. Destacaba un frontal de altar "de planchas de oro de martillo y con mucha imaginería de bultos, guarnecido con catorce piedras preciosas de gran tamaño, veinte y quatro granos de aljófar muy crecidos y veinte y tres esmaltes grandes; obra todo ello del célebre Maestro Almanio, labrada por encargo de don García y de su esposa"21.

Por muy célebre que fuera en su tiempo, nada se conserva de este artífice. Pero nos interesa especialmente resaltar que entre los objetos de la donación que hizo don García figuraba la Cruz de su bisabuelo Sancho Abarca, realizada por orfebres árabes, según mostraba la inscripción que llevaba en su pie. La Cruz se conservaba todavía en Nájera cuando la describe el obispo de Pamplona: de oro fino, casi de una vara de alta, de mucho peso, toda sembrada de pedrería y joyas de gran valor, y con el pie también de oro macizo y lleno de piedras, "entre las cuales tenía una de tanto resplandor, que puesta en el Altar y reflejando en una cualquiera luz lejana, alumbraba con la intensidad de un hacha, tanto que podian los monges leer a su claridad el Breviario"z2.

19. VERGAZ, Miguel Ángel, "La RAE avala que Burgos acoge las primeras palabras escritas en castellano", El Mundo, 7 de noviembre de 2010, http://www.elmundo.es/elmundo/2010/11/07/castillayleon/1289123856.html, (consultado en mayo de 2017).

20. Prudencio de Sandoval, obispo de Pamplona, escribe su primer libro Noticias históricas del real Monasterio de Nájera antes de 1598 , durante la época en la que fue Prior del Monasterio (Cf. SANDOVAL, Prudencio de, Catálogo de los obispos..., op. cit., Madrid, 1601. YEPES, Antonio de, Corónica General de la Orden de San Benito, vol. 6, 1617, folio 126. Cf. también MORET, José, Investigaciones Historicas de las antigüedades..., op. cit.; y GARRÁN, Constantino, Santa María la Real de Nájera. Memoria histórico-descriptiva, Logroño, Establecimiento Tipográfico de La Rioja, 1892, pág. 13. Todo ello ha sido estudiado en MOYA VALGAÑÓN, Migué Ángel, El arte en la Rioja (I): La Edad Media, Logroño, Diputación de La Rioja, 1982, pág. 19.

21. Alrededor en letras del tiempo tiene la inscripción siguiente: Hec rex piissimus fecit Garsea benignus, Et me Stephanie factum sub honore Marie Scilicet Almanii decus artificis venerandi. Que se traduciría así: "Todo esto que ves, lo hizo el rey García dadivoso y piadosísimo: y a mi dióme el ser la reina Estefanía, para honor de María, confiando tan hermosa obra a la pericia de Almanio, artífice admirable". En las sucesivas donaciones de la viuda de García, doña Estefanía y de su hijo Sancho el de Peñalén se menciona un segundo altar de oro con dos representaciones en bulto, de la Visitación y de la Anunciación, que era similar al anterior en su factura, y en su decoración de piedras preciosas. Ibídem.

22. SANDOVAL, Prudencio de, Catálogo de los obispos..., op. cit. 
El padre Yepes añade a estas descripciones que la susodicha piedra brillante desapareció con el pie de la cruz que tomó para sí "el Emperador D. Alonso VII" para regalársela a Luis VII de Francia, quien la colocó en un espinario de Saint Denis. Habla del carbunco (sic.) del pie de la cruz desaparecido como algo tan excepcional que seguía siendo recordado a pesar de su larga ausencia. Y confirma que la Cruz estaba "toda sembrada de pedrería y joyas de gran valor, que es cierto que mirándola un lapidario del emperador Carlos V, pasando su majestad por Nájera, este maestro dijo que aquella cruz tenía una piedra que valía más que Logroño, y su majestad le mandó que no descubriese cuál era porque no la hurtasen "23.

No es esta la gema que ahora nos ocupa, pero ilustra muy bien que la Cruz tenía un valor excepcional, aunque nada quede de ella salvo el "rubí" Príncipe Negro. Tampoco hay documentación sobre la presencia del "rubí” en Saint Denis, pero puede ser interesante señalar la vinculación que se establece entre esta joya y las reliquias de la espina de Cristo. En primer lugar, este dato de la crónica de Yepes ilumina sobre el porqué del nombre espinela con el que Georgius Agricola (De Re Metallicae, 1555) designó a los balajes; en segundo lugar, sirve para justificar algunos de los argumentos que veremos a continuación en relación con la Cruz de Sancho Abarca y la simbología de la espinela colocada originariamente a sus pies.

El padre Moret contradice la hipótesis de Yepes, y da una información más detallada de la Cruz de Sancho Abarca puesto que reescribe la inscripción de sus donantes "por haberla sacado Sandoval con algunos yerros ${ }^{224}$, aunque él mismo confunde los datos de Sandoval, pues dice que el artífice de la cruz fue Almanio y no es así. Todo se debe a problemas con la repetición generacional de los nombres Sancho y García en la dinastía Abarca. Pero es interesante que el padre Moret especifique que se conservaba en la cruz la inscripción siguiente:

"En el Nombre de Cristo. Esta Cruz sagrada fue hecha en honra de San Esteban Levita primer Martyr. Y es memoria del Príncipe Don Garcia. Yo Don Sancho Rey su Hijo, en uno con mi Muger la Reyna Doña Urraca, la mandamos labrar. Rogamos a todos vosotros, los que esto leyeredeis, no seais perezosos en orar por su Alma, y por Nosotros. Para que, ayudados de vuestros sufragios, tengamos con vosotros parte en los Reynos Celestiales, Amen"25.

Este Don García nombrado es el I de la Dinastía Jimena, padre de Sancho Abarca. García el de Nájera es el III, y de su época, medio siglo después, es el maestro Almanio. Desconocemos el artífice de la Cruz, aunque debía ser árabe pues aparecían también signos en esta lengua en la Cruz. La última descripción visual de ella se debe al ilustrado Jovellanos, que la vio en la sacristía del monasterio en sus viajes de 1795 y 1801, conteniendo todavía las reliquias de los dientes del protomártir San Esteban. La compara con la cruz de la Victoria de Oviedo, y dice que era de madera cubierta de chapas de oro con guarniciones de filigrana y camafeos, entre ellos dos con inscripciones árabes, y piedras preciosas (rubíes, zafiros, amatistas, esmeraldas - "las más sin labrar y todas sin abrillantar"6).

23. YEPES, Antonio de, Coronica general..., op. cit., folio 126.

24. MORET, José, Investigaciones Historicas de las antigüedades..., op. cit., pág. 448.

25. Ibídem, pág. 449.

26. JOVELLANOS, Gaspar Melchor de, Obras Completas, Madrid. B.AA.EE. 1956, volumen III, págs. 272-273. Jovellanos recoge completa la inscripción latina: "In xpi nmne hanc crucem almam ob honoren Sci Steffani Levite et martiris primi est facta me pigeatis qualiter vestris adjuti sufragis habeamus vobiscum partem in celestibus regnis amen et est memoria Dni. Garzeani princeps ego Santio rex et filius eyus simul cum uxore mea Urraka Regina fieri jussimus igitur obsecramus vos omnes qui hec lexeritis pro anima eyus et pro nobis orare". Describe también como algo excepcional el famoso becerro en cuatro tomos con las escrituras hasta 1500. 


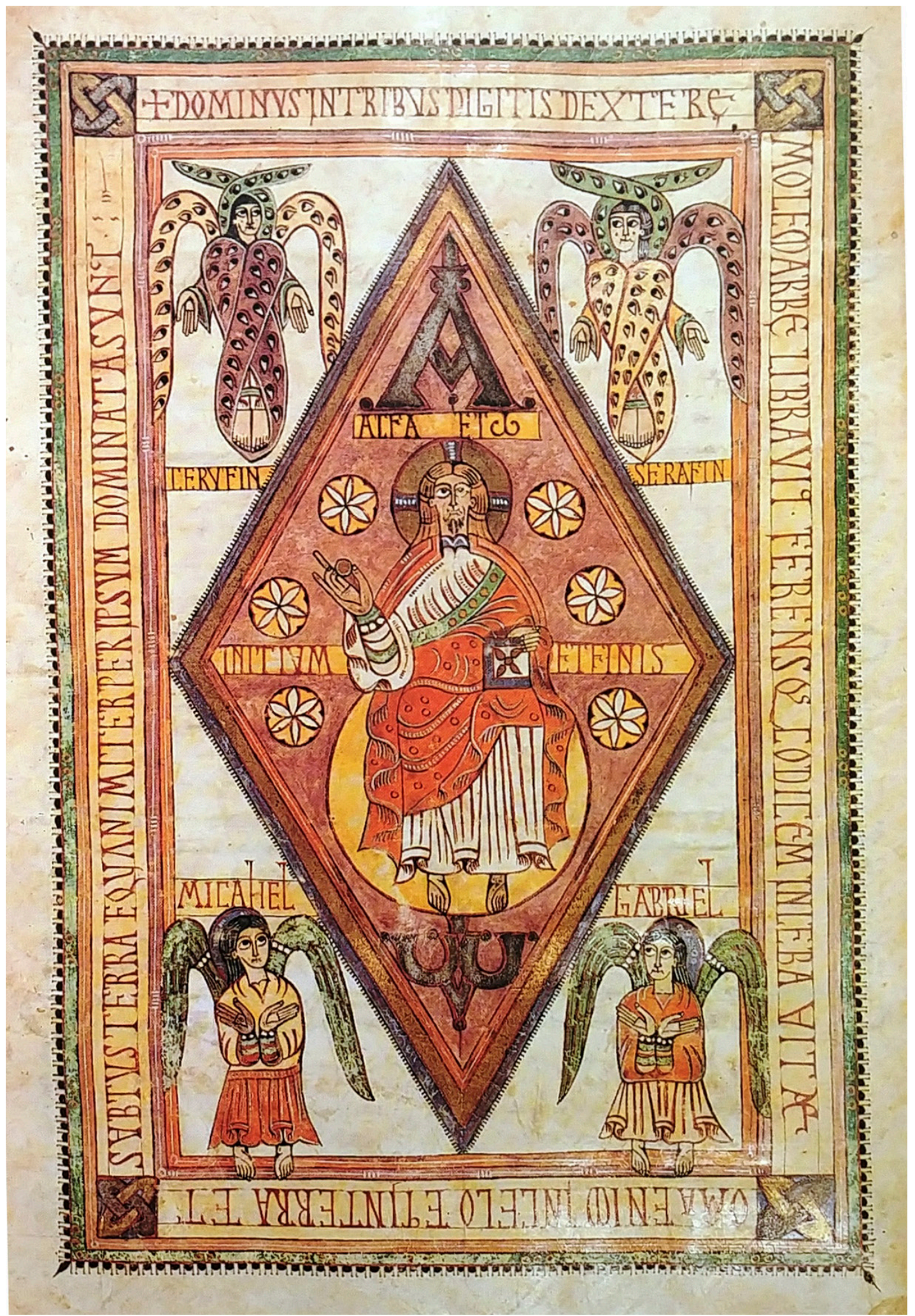

Fig. 4. Maiestas Domini, Códice conciliar Vigilano, Manuscrito 976, fol. 16v. (San Lorenzo de El Escorial). Fotografia del autor. 


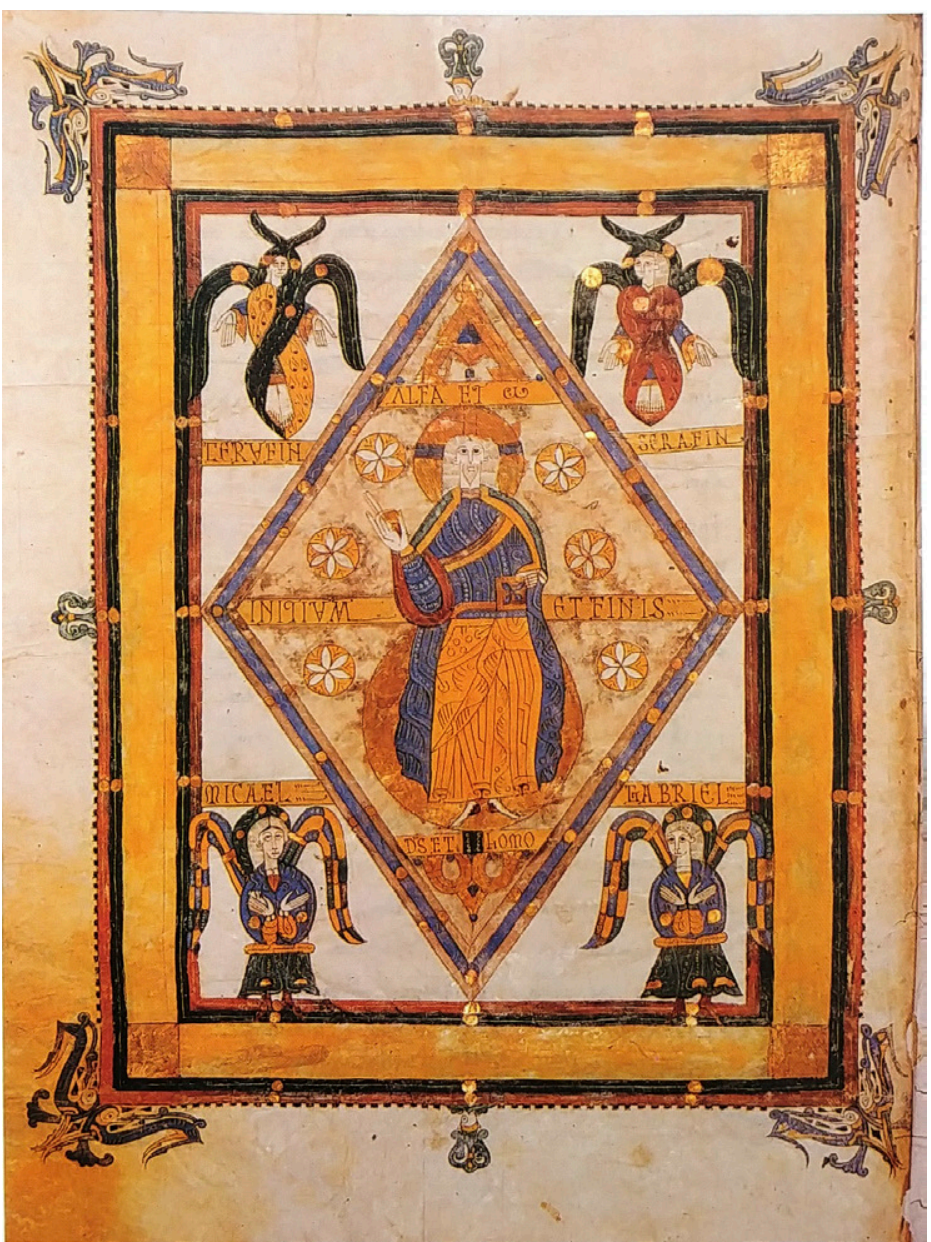

Fig. 5. Maiestas Domini, Códice conciliar Emilianense. Sig. D.I.I, Año 992 (San Lorenzo de El Escorial), http://www.vallenajerilla.com/albeldense/index.htm, (consultado en mayo de 2017).
Tras la guerra de la Independencia y la Desamortización de Mendizábal poco se ha conservado del impresionante tesoro de Santa María la Real de Nájera. Pedro de Madrazo describe dolorosamente el monasterio desvalijado en el que todavía se podía ver la capilla real o de la Cruz, anexa a la cueva (ya totalmente perdida por la restauración del siglo $\mathrm{XX}$ ); y registra la disparidad de criterios que se da entre Sandoval y Moret, que dice que la piedra no desapareció en el siglo XII sino después de la batalla de Nájera ${ }^{27}$. Y esto mismo defiende Constantino Garrán, después de contrastar todos estos datos históricos mencionados con los que aportaba el becerro perdido del Cartulario de Santa María la Real ${ }^{28}$.

Es preciso recordar que a la Cruz de Sancho Abarca le faltaba el pie en tiempos del rey Pedro, por lo que la piedra preciosa, si seguía en Nájera, pertenecía ya al ajuar de la Virgen, tal como se detallaba en el becerro perdido durante la Guerra Civil. Se había roto por tanto la tradición original que vinculaba a este tipo de joyas balaj o espinela con un elemento eucarístico, como veremos a continuación, en relación

con los códices riojanos conservados en las Bibliotecas Nacional de España y en la de El Escorial.

\section{El carbunclo de la Maiestas Domini de los códices Albeldense y Emilianense}

Son muchos los manuscritos riojanos que se conservan en las colecciones de Patrimonio Nacional, pero nos interesan ahora especialmente analizar las ilustraciones del Códice Vigilano y en su copia Emilianense, realizada por el escriba-miniaturista Velasco. Además de los retratos de reyes antes mencionados, son muy peculiares las representaciones de los concilios de Toledo, y el famoso mapamundi de la época postdiluviana, que acompaña a episodios bíblicos sobre los que hablaremos más adelante. Pero para poder comprender bien la información iconográfica que estas miniaturas encierran es preciso proponer una interpretación de las

27. MADRAZO, Pedro de, Navarra y Logroño, en España, sus Monumentos y Artes - Su Naturaleza e Historia, Barcelona, 1886, pág. 633.

28. Cf. relación el día 11 de noviembre de la Era 1417 (año de Cristo 1379) en GARRÁN, Constantino, "El Becerro de Santa María la Real de Nájera", op. cit., pág. 387. 
Maiestas Domini del Códice Vigilano o Albeldense y del Emilianense (Figs. 4 y 5) diferente a la dominante en los estudios canónicos sobre ilustraciones medievales de la época.

La Maiestas Domini de ambos códices sostiene con tres dedos de la mano derecha una pequeña esfera de color rojizo que ha sido interpretada como el orbe, atribuyendo un error en la inscripción que recorre todo el marco rectangular de la composición, que, con algún signo de abreviatura, dice así:

+ DOMINUS IN TRIBUS DIGITIS DEXTERE MOLEM ARBE LIBRAVIT - FERENS QS CODICEM IN LEBA VITAE - OMA ENIM IN CAELO ET IN TERRA -ET SUBTUS TERRA EQUANIMITER PER IPSUM DOMINATA SUNT

La experta de referencia sobre las miniaturas riojanas, Soledad de Silva, siguiendo a otros autores, mantuvo la tesis de que Arbe debía ser Orbe, pues solo así se entiende el texto en relación con la definición isidoriana del mundo en sus Etimologías, cuyo libro XIV se titula precisamente De Orbe $e^{29}$. Además, contamos con el precedente del Beato de Gerona, contemporáneo al Códice Vigilano, en el que junto a la pequeña esfera que sujeta la Maiestas Domini aparece la palabra "mundus".

Esta interpretación de la piedra preciosa rojiza como una esfera o mundo ha condicionado las lecturas posteriores de la Maiestas del Vigilano, cuya inscripción no se sabe entonces si remite al futuro, como es propio de los aspectos apocalípticos que recoge la simbología dominante en esta imagen, o al pasado, en relación con el Génesis y la Encarnación, pues emplea el verbo libravit:

"Plusieurs indices majeurs contredisent pourtant une telle lecture. La theophany du codex Albeldense, dans laquelle figurant un chérubin, un séraphin et les archanges Michel et Gabriel, est accompagnée d'un titulus évoquant explicitement le jugement divin, mais le verbe y est conjugué au passé et semble dès lors exclure l'ultime jugement'30.

Pero, todavía más importante, se trata de una interpretación que ha condicionado la lectura simbólica de las Maiestas carolingias que les sirvieron de modelo ${ }^{31}$ (Figs. 6 y 7), en las que Cristo aparece descalzo y sujetando una pequeña esfera en su mano derecha.

Habría dos interpretaciones acerca del significado de este motivo circular presente en tempranos ejemplos carolingios. La primera lo identifica con el mundo, buscando su fuente literaria en unos versos de Alcuino en relación con las fuentes citadas y, como prueba más directa, en las inscripciones de la Majestad gerundense ("mundus") y del Albeldense, interpretada como orbe la palabra arbe $e^{32}$. La segunda teoría, puesta

\footnotetext{
29. SILVA Y VERÁSTEGUI, Soledad de, Iconografía del siglo X en el reino de Pamplona-Nájera, Pamplona, Príncipe de Viana/Instituto de Estudios Riojanos, 1984, pág. 209 y "La miniatura en el Reino de Pamplona-Nájera (905-1076)", op. cit., pág. 334

30. ANGHEBEN, Marcello, "Theophanies absidales et liturgie eucharistique. L'exemple des peintures romanes de Catalogne et du nord de Pyrenees comportant un seraphin et un cherubin", GUARDIA, Milagros y MANCHO, Carles, Ars picta, Temes 1, Universidad de Barcelona, 2008, pág. 71. La misma confusión puede verse en FERNÁNDEZ GONZÁLEZ, Etelvina y GALVÁN FREILE, Fernando, "Iconografía, ornamentación y valor simbólico de la imagen", Códice Albeldense, 976, Colección Scriptorium, 15, 2002, págs. 223-225. Cf. también GALVÁN FREILE, Fernando, Imágenes del poder en la Edad Media. Selección de estudios del prof. Fernando Galván Freile. Tomo I. León, Universidad de León, 2011, o FERNÁNDEZ GONZÁLEZ, Etelvina, Imágenes del poder en la Edad Media. Estudios in memoriam del prof. Fernando Galván Freile. Tomo II, León, Universidad de León, 2011.

31. Cf. por ejemplo la Biblia de Vivian (folio 330v); Evangeliario de Dufay (París Biblioteca Nacional, Ms. Lat. 9385. H. 850, escuela de Tours, folio 179v); Evangelios de Le Mans (París B. N. Ms. Lat. 261, siglo IX, escuela de Tours, f. 18); Codex Aureus (folio 6v); los dos ejemplos del Sacramentario de Metz (ff. 5 y 6); la Biblia de Carlos el Calvo que se encuentra en San Pablo Extramuros (folio 257v).

32. Cf. MEER, Frederick van der, Maiestas Domini, Roma, Città del Vaticano, 1938, págs. 333-334; KESSLER, Herbert L., The Illustrated Bibles from Tours, Princeton
} 


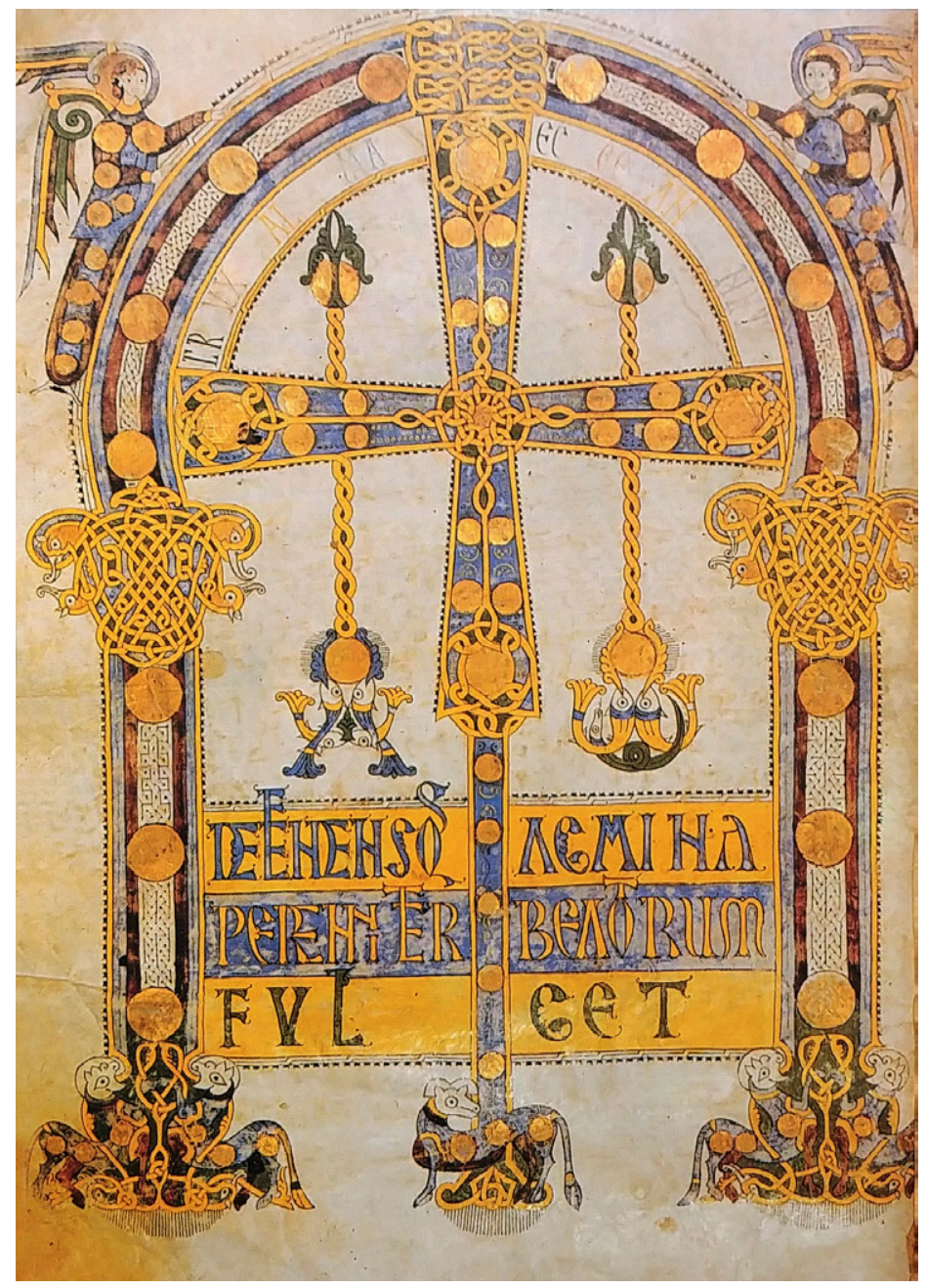

Fig. 6. Sacramentaire de Carlos el Calvo, París, BnF, ms. lat. 1141, f. 6. De J. Hubert, J. Porcher et W.F. Volbach, L'empire.

plos tempranos carolingios exista un significado eucarístico redentor ${ }^{34}$.

La relectura del Códice Vigilano y Emilianense que proponemos a continuación, estaría en relación con esta última interpretación. Lo que las Maiestas llevan en la mano sería una moneda, o un objeto de valor semejante, para pagar el rescate, en concordancia con su último significado Apocalíptico:

"Voy a llegar enseguida, llevando mi salario para pagar a cada uno conforme a la calidad de su trabajo. Yo soy el alfa y la omega, el primero y el último, el principio y el fin” (Ap 22, 10-13).

N. J. Princeton University Press, 1977, págs. 36 y 42; SILVA Y VERÁSTEGUI, Soledad de, Iconografía del siglo X en el reino de Pamplona-Nájera, Pamplona, op. cit., pág. 209.

33. Cf. SCHAPIRO, Meyer, "Dos dibujos románicos de Auxerre y algunos problemas iconográficos", VV. AA. Estudios sobre el románico, Madrid, Alianza Forma, 1984.

34. KUME, Junko, "Aspectos de la influencia iconográfica carolingia en la miniatura hispánica de los siglo X y XI", CABAÑAS BRAVO, M. (edit.), El arte foráneo en España: presencia e influencia, Madrid, CSIC, 2005, pág. 209. Este autor hace referencia al temprano estudio de COOK, Walter William Spencer, "The Earliest Painted Panels of Catalonia (II)", Art Bulletin, VI, 1923, págs. 52-65. 
Los colores dorados con los que se presenta esta pequeña esfera en los ejemplos carolingios refuerzan esa tradición iconográfica particular que inspiraría a los códices riojanos, y los distanciaría del Beato de Gerona. Iconográficamente, el círculo pequeño rojo que sostiene con los dedos de su diestra el Señor en majestad no puede ser el mundo, pues en los códices riojanos aparece sentado en él, mientras que en el beato de la catedral de Gerona se trata de un simple trono.

\section{El simbolismo redentor del carbunclo riojano}

Las gemas tenían por aquel entonces un valor simbólico monetario, pues no existía todavía moneda de curso legal propia en el joven reino de Pamplona-Nájera, a diferencia de lo que sí ocurría en el mundo carolingio que le sirve de referencia iconográfica. Así interpretado, junto a la correcta traducción de ARBE como ARBORE, una apócope lingüística perfectamente posible, cobraría pleno sentido el simbolismo del carbunclo que la Majestad sujeta con tres dedos:

+ EL SENOR CON TRES DEDOS DE SU MANO DERECHA IGUALÓ EN LA BALANZA EL GRAVAMEN DEL ARBOL [DEL CONOCIMIENTO DEL BIEN Y DEL MAL] A QUIENES LLEVA EN EL LIBRO DE LA VIDA EN SU MANO IZQUIERDA - PUES HA QUEDADO IGUALMENTE SOMETIDO POR ÉL TODO CUANTO HAY EN EL CIELO Y EN LA TIERRA Y BAJO TIERRA

Esta lectura soluciona los problemas de interpretación de Soledad de Silva y la mayoría de los estudiosos del Códice Vigilano. Es cierto que la mención explícita a los tres dedos que hace el Vigilano podría recordar la cita de Isaías 40, 12, que tiene ecos en los Salmos, y era muy comentada en la época carolingia ${ }^{35}$ :

"Quis mensus est pugillo aquas, et caelos palmo ponderavit? quis appendit tribus digitis molem terrae, et liberavit in pondere montes, et colles in statera? (¿Quién midió a puñados las aguas y exploró la medida de los cielos a palmos? ¿Quién sostuvo a pulso con tres dedos la masa de la tierra y pesó en la báscula los montes y las colinas con la balanza?)' ${ }^{36}$.

Aunque demos por aceptable esta posible base bíblica como fuente inmediata del primer dístico del dominio sobre el mundo, es seguro que se ha modificado teológicamente esta cita, fundiéndola con otras del Apocalipsis canónico. Mientras Isaías hace depender "molem terrae" de "appendit" (con acusativo y genitivo), el escriba Vigila lo hace depender de "libravit" (con acusativo y ablativo), poniéndolo de este modo en relación con los textos apocalípticos sobre el Libro de la Vida. Por esta razón, inserta la referencia a la mano derecha con su significado bíblico de salvación y poder, que está ausente en el texto profético. En definitiva estamos ante cuatro dísticos en prosa rítmica que reelaboran y funden diversos textos bíblicos de uso común en las lecturas monásticas, junto con tradiciones propias del momento en que se escribe el texto ${ }^{37}$.

La transcripción de la inscripción latina que permite integraciones evidentes desde el punto de vista ortográfico (QUOS por QS, LAEVA por LEBA, COELO por CELO, AEQUANIMITER por EQUA-

\footnotetext{
35. Cf. por ejemplo: Haymo Halberstatensis, Commentaria in Isaiam, PL 116, 0911C (auctor -853): "Quis appendit tribus digitis molem terrae id est quis suspendit terram super nihilum, nisi potestas Trinitatis, Pater et Filius et Spiritus sanctus?"

36. Biblia Sacra iuxta Vulgatam Clementinam, VT, Is, 40; 12

37. Las balanzas romanas, al tener un solo brazo, requerían un procedimiento de ir ajustando el equilibrio de la balanza desigual mediante contrapesas acuñadas con su valor específico.
} 
NIMITER) no nos autoriza a cambiar totalmente la palabra “ARBE” por “ORBE”. El tipo de letra usado por el escriba en la inscripción de ARBE hace que tengamos que leer ARBOE o ARBAE como hacemos en DEXTERAE, pues se trata del mismo tipo de E diptongada final, que nunca se utiliza en el caso de las E corrientes del interior de palabra. Solo al final del colon se escribe completa VITAE para adorno final y no VITE, como sí se hace con DEXTERE y ORBE/ARBE. Tampoco la morfología permite un uso del ablativo por genitivo como sería si aceptamos que ORBE remite al volumen del mundo que es pesado, pues entonces debería decir ORBIS ${ }^{38}$.

Al mismo tiempo, esta imaginería apocalíptica de pago o rescate se adapta perfectamente a la lectura iconográfica sacramental de la joya de color rojo que sostienen las Maiestas riojanas de modo atípico, levantados el meñique y el índice, gesto que no aparece en otros saludos de majestades similares, incluida la de Gerona.

Aunque no había una norma demasiado rígida al respecto, la bendición con tres dedos se interpreta como fiel al canon ortodoxo postcalcedoniano de las tres personas y las dos naturalezas, otorgando de este modo simbolismo al uso de los cinco dedos $(3+2)$. Si lo que llevan en la mano las majestades carolingias es el salario del rescate, creemos que el sentido más plausible de la inscripción del Vigilano hace referencia a una joya que simboliza la redención de Cristo mediante su sangre, con la que se nivela la balanza del pecado del hombre (el peso moral -gravamen- del árbol del conocimiento del bien y del mal). El hecho de que sujete un rubí con tres dedos, serviría para dejar claro, contra toda remanencia arriana y prisciliana, que la Redención proviene de las tres Personas divinas aunque solo la segunda Persona muera en la Cruz.

Al mantener Arbe como Arbore, toma sentido también la conexión que hace a lo largo del Códice el ilustrador entre el Génesis y el Apocalipsis, la referencia al Pecado y al Juicio Final, unidos ambos por la Redención trinitaria. El peso, mole o gravamen del árbol del que el Señor Todopoderoso redime a los que están presentes en el libro de la Vida sería el pecado original; la caída que trajo la mortalidad y el mal que gobierna el mundo, al que se refiere la inscripción, que vemos más desarrollada en otra escena del Códice, la representación del tapiz de Noé y sus hijos, con el Mapamundi y el Paraíso perdido con el Árbol de la Vida protegido por querubines con espadas incendiarias (El Escorial. Biblioteca del Monasterio. Ms. D.I.2, f. 17v).

Se entiende así también que el verbo esté en pasado, en referencia al Génesis y al pecado original, aunque se trate al mismo tiempo de la representación del Juicio Final propia de estas Maiestas que portan el Libro de la Vida ${ }^{39}$.

Aunque el Códice Vigilano tiene muchas influencias mozárabes, y recoge por primera vez en Europa la numeración arábiga siglos antes de que se generalizara en Occidente, conceptualmente está más relaciona-

\footnotetext{
38. Por todo esto, pensamos que la traducción tiene un sentido teológicamente seguro leyendo como ÁRBORE el ARBOE de la inscripción, mientras que sustituirlo por un ORBE es de imposible fundamento. Teniendo en cuenta que esta palabra sincopa o apocopa en muchas lenguas romances (en castellano dará ÁRBOLE, ÁRBOL) nos parece fácil la integración, como hacemos en CAELO, LAEVA, AEQUANIMITER, aunque en este caso se trate de la R que vacila en la asimilación con la líquida $L$.

39. Evidentemente, en los códices Albeldense y Emilianense, Cristo sentado en un globo, a modo de trono celestial, rodeado de estrellas y acompañado de dos querubines con seis alas -si bien uno de ellos aparece designado como serafín-, evoca el libro del Apocalipsis. Como en el Sacramentario de Metz, el de Carlos el Calvo, la cubierta de marfil de San Gall, etc., todos ellos siguen las fuentes bíblicas que describen la presencia de querubines en la Majestad (Is. 6; Ex. 25: 17-22; Ez. 9:3; Sal. 18: 11, 99: 1).
} 


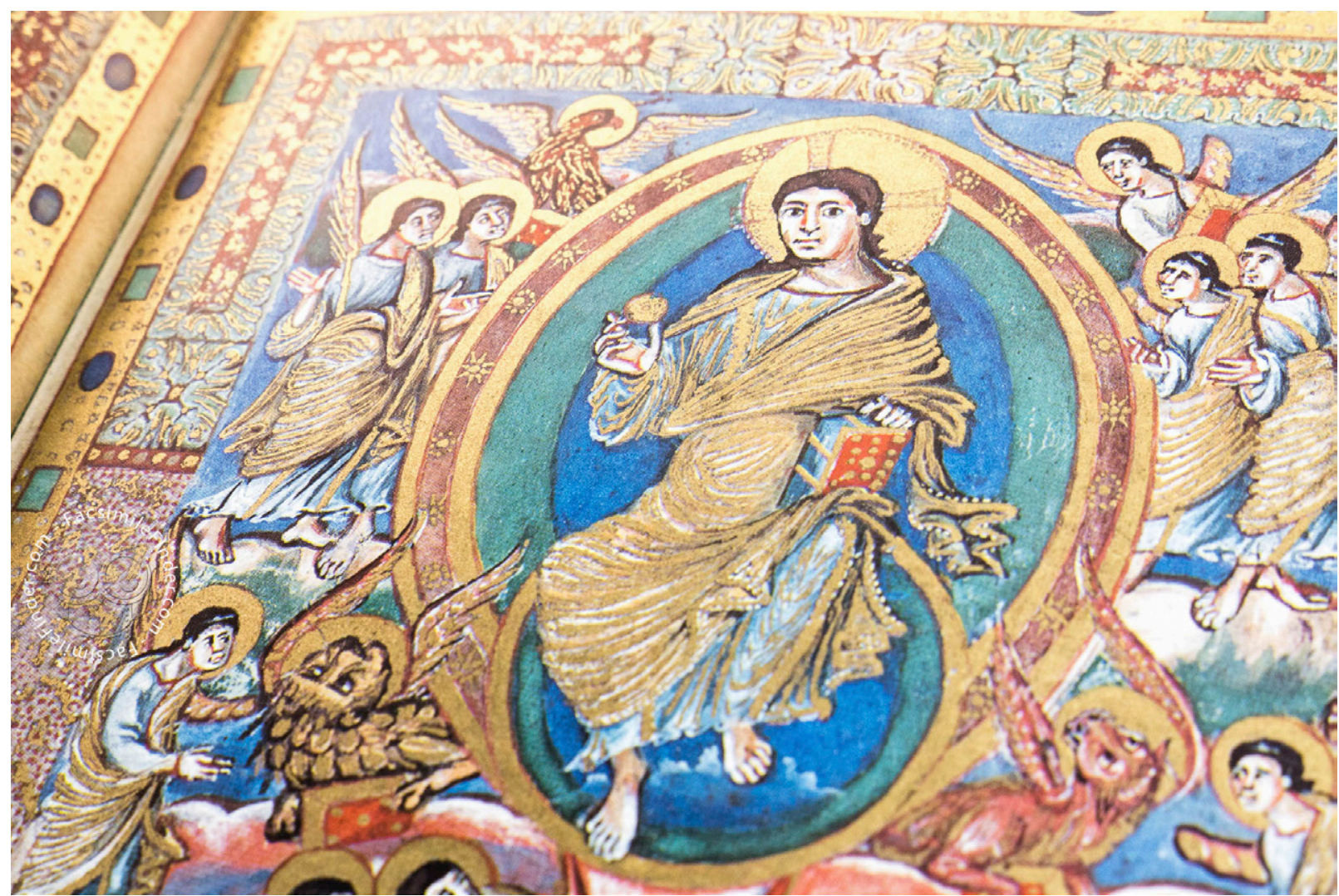

Fig. 8. Cruz del Códice conciliar Emilianense con pie y ángeles fol. 16v. (San Lorenzo de El Escorial). Fotografia del autor.

do con las tradiciones del norte de Europa que los famosos beatos, incluidos los que salieron de los escritorios de San Martín de Albelda y San Millán de la Cogolla, que hoy se encuentran en la Biblioteca Nacional y en El Escorial ${ }^{40}$. No es el fin de este estudio ambicionar tanto, pero quizás el ejemplo de Gerona obedece a que existían ya entonces otras atribuciones simbólicas distintas para las pequeñas esferas que sujetan las Maiestas Domini europeas de los siglos IX y X; y por eso era preciso especificar con la palabra "mundus" el significado de este caso particular. Mientras aparecen nuevos datos que permitan demostrar este simbolismo polivalente, es importante señalar que la Maiestas de los códices Vigilano y Emilianense presenta peculiaridades propias, distintas a la del Beato de Gerona.

En conclusión, la iconografía simbólica sacramental y trinitaria que caracteriza a las Maiestas riojanas haría referencia al concepto Árbol y no a Orbe, según un supuesto error de escritura muy difícil de explicar científicamente. La correspondencia en quiasmo entre la mano derecha y la izquierda, la balanza del juicio y el Libro de la Vida, y la cita casi literal de Flp. 2, 6-11 hacen evidente que su contenido en pasado se refiere a la redención de la humanidad, obrada por la muerte sacrificial de Cristo, pero identificada, como hace el Apocalipsis, con el juicio futuro de su última Venida como juez de vivos y muertos, ya que

40. De las ocho copias ilustradas del Comentario de Beato que conservamos del siglo X, tres se relacionan con San Millán de la Cogolla: Los Beatos de la Biblioteca Nacional de Madrid (ms. vitr. 14-1), el de la Biblioteca del Real Monasterio de El Escorial (\&. 11.5) y el de la Academia de la Historia (cod. 33). Todas las ilustraciones del Vigilano en http://www.vallenajerilla.com/albeldense/index.htm, (consultado en mayo de 2017) y también algunas del emilianense en http://www.vallenajerilla.com/berceo/silvaverastegui/talleremilianense.htm (consultado en mayo de 2017). 
"en la cruz, el mundo está siendo juzgado como reo, y el crucificado exaltado como juez poderoso" (Misal romano, prefacio de pasión I).

La espinela tenía por tanto una simbología relacionada con el sacrificio redentor de Cristo, y no es extraño que, finalmente, se dispusiera en el pie de la cruz anicónica encargada por Sancho Abarca siguiendo los modelos visigótico-mozárabes y asturianos. El pie es un lugar en el que frecuentemente aparece representado el Cordero místico, como puede verse en los Beatos y en las cruces de los códices Vigilano y de San Millán (Fig. 8), que sigue el modelo de la Cruz de los Ángeles de Oviedo, de modo literal.

Una Cruz que lleva la siguiente inscripción latina, tanto en el Emilanense como en el Vigilano (fol. 18v.):

CRUX ALMA ECCE ANNET DEFENDENS QUOS AGMINA PERENNITER BEATORUM FULGET (Mira cómo reluce la cruz fecundalque defiende a las escuadras de los bienaventurados/ a quienes permanentemente alumbra).

\section{La Cruz como árbol de la Vida}

Es importante recordar que las cruces griegas con pie de tradición visigótica y asturiana remitían al árbol de la Vida, además de ser el símbolo de la Victoria para los elegidos, comenzando por el propio Cristo, nuevo Adán, vencedor en el árbol de la cruz sobre el mal que trajo el árbol del pecado. Su significado era tanto religioso como político, un estandarte en la reconquista frente al Islam. Es en este sentido de victoria como debe interpretarse el relieve real de Luesia (Zaragoza) y San Miguel de Villatuerta (Navarra), también del último tercio del siglo X, que parece evocar el momento de la ceremonia en el que el rey Abarca -caracterizado por la corona- recibe la cruz de manos del obispo y la presenta al diácono que ha de ser su portaenseña durante los días de la campaña ${ }^{41}$.

Seguramente, los miniaturistas de los códices riojanos tenían muy presente ambos significados cuando escogieron como símbolo del precio del rescate la importante gema que Sancho Abarca había situado en un lugar privilegiado de su Cruz, el que ocupa el cordero místico en el mismo pie. La Cruz se convierte así en un estandarte, en el árbol de la Vida. Y por eso los poderes milagrosos de sanar sólo con mirarla que se le atribuían, tal como describe el padre Yepes siguiendo testimonio del obispo Sandoval ${ }^{42}$. Pero los testimonios arqueológicos son igual de elocuentes. Era tanta la devoción que despertaba esa Cruz de Sancho Abarca, que dio nombre a una capilla en Santa María la Real de Nájera, con título propio dentro del monasterio ${ }^{43}$, y se

\footnotetext{
41. Están a punto de salir dos publicaciones en las que estudio este tema en profundidad. Cf. por ejemplo, la llamada «cruz del secreto» tal como aparece figurada en un pilar visigodo, similar a la asturiana de la Victoria, con el alfa y el omega- que según Menéndez Pidal "se nos ofrecen como supervivencias que testifican de qué manera aquella costumbre visigótica, según la cual los reyes ofrecían como dones cruces preciosas a sus iglesias, siguió siendo practicada por los reyes asturianos deseosos de persistir en los modos toledanos". MENÉNDEZ PIDAL, Gonzalo, "El lábaro primitivo de la reconquista", Varia Medievalia I, Madrid, Real Academia de la Historia, 2003, pág. 58.

42. "Son grandes los milagros que Dios ha obrado y obra por medio desta santa Cruz y en estos días ay en esta casa monges graves, y de todo crédito dignos, que los han visto, y en el pueblo ay otros muchos, y en el archivo se hallan testimonios de otros que han sucedido años atrás. Es particular la virtud que ha mostrado de sanar los ojos, y de algunos muy señalados, y frescos milagros, haré relación para que nuestro Señor sea loado en sus obras, y estas no se olviden, sino que queden en perpetua memoria, y la devoción a la santa cruz se aumente". YEPES, Antonio de, Coronica general..., 1617, op. cit., pág. 126.

43. No hay que confundirla con la actual capilla funeraria de la Veracruz, situada en el claustro. La primitiva parroquia de la Santa Cruz, se fundó en el año 1052, el de la fundación del monasterior, y se mantuvo con clérigos seculares después dentro del Monasterio cluniacense de Santa María la Real hasta su separación en 1230, por un decreto del Papa Honorio III (separación de clérigos seculares de la autoridad de los regulares). La actual Iglesia parroquial de la Santa Cruz de
} 
convirtió en el símbolo más importante del reino de Nájera-Pamplona, como puede verse en las monedas de los reyes de esta dinastía, algunas de ellas, las más antiguas, acuñadas en Nájera ${ }^{44}$.

Todavía siglos después, la Corona de Aragón recuerda sus orígenes navarros con este símbolo de una cruz griega sobre un árbol que, por confusión, acabó llamándose Cruz de Ínigo Arista, o del Sobrarbe, aunque en realidad se remonta a la dinastía Jimena o Abarca ${ }^{45}$. No olvidemos que Ramiro era hijo bastardo de Sancho el Mayor y solo su hijo Sancho Ramírez se atrevió a titularse oficialmente rey de Aragón, por ser también de Pamplona (tras el asesinato en Peñalén del hijo de García el de Nájera, Sancho Garcés IV, en 1076). Con los documentos falseados de San Juan de la Peña, donde se adelanta el título de reino de Navarra al reinado de Sancho II Abarca, lo que es del todo imposible, se quería borrar la historia riojana del reino de Nájera-Pamplona, una vez que aquellas tierras habían pasado a formar parte de Castilla-León ${ }^{46}$.

Se trata de viejas polémicas que siguen vivan en cuestiones históricas todavía en discusión, como hemos visto en referencia al origen del castellano. Ni siquiera puede demostrarse dónde se encuentra realmente la tumba del rey Sancho II Abarca, si en Leyre, en San Juan de la Peña o en Santa María la Real de Nájera, pues los tres monasterios se la atribuyen en sus cartularios y conservan cenotafios en sus panteones. Por eso, cuando los documentos históricos se escriben de modo tan interesado ${ }^{47}$, es preciso prestar atención a las imágenes de época. Y los códices Vigilano y Emilianense son una fuente fundamental en la verificación de los orígenes riojanos de la emblemática espinela del Príncipe Negro y su presencia en la Cruz de Sancho Abarca que tanta admiración provocó en los monarcas que le sucedieron y en los testigos cronistas que la describieron.

\section{Conclusión}

Georgius Agricola se inspiraba en tradiciones simbólicas medievales al denominar Spinela a los balajes de color rojizo (pues, a diferencia del rubí, la espinela puede ser de muchos colores). Los expertos en joyas históricas dicen que el nombre procede de la palabra latina spina, por la forma puntiaguda de sus cristales más habituales, los octaédricos ${ }^{48}$. Cabría también la opción de que el término derivara del griego spinos, que significa "chispa", en alusión al color brillante de luz rojiza, a su aspecto centelleante y luminoso. En todo caso, ambas teorías son complementarias, y explican que las espinelas fueran muy apreciadas en la Edad Media por su carácter simbólico, relacionado tanto con la sangre de Cristo como con la luz del Espíritu Santo, que actúa a través de los sacramentos.

Nájera fue consagrada en 1611, pero sus orígenes se remontan a García el de Nájera y a la Cruz de Sancho Abarca. Cf. GARRÁN, Constantino, Santa María la Real de Nájera. Memoria histórico-descriptiva, op. cit.

44. Cf. JUSUÉ SIMONENNA, Carmen y RAMÍREZ VAQUERO, Eloísa, La moneda en Navarra, Pamplona, Gobierno de Navarra, 2002.

45. La continuidad iconográfica de las monedas desde Sancho el Mayor hasta la época de Sancho VI el Sabio, que devolvió brevemente Nájera al reino de Pamplona, es muy elocuente al respecto.

46. Se trata de una carta de donación de la villa de Alastuey hecha por el rey de Pamplona al monasterio de San Juan de la Peña en 987, en la que se dice: "reinando Yo, D. Sancho, rey de Navarra, en Aragón, en Nájera y hasta Montes de Oca...". Pero los historiadores han demostrado la falsedad de este documento, puesto que la primera noticia de la existencia de Alastuey data del año 1090, cuando el rey Sancho Ramírez de Aragón concedió los derechos eclesiásticos de la villa al cabildo de Jaca y los tributos reales al monasterio de San Juan de la Peña. Y la denominación de Navarra no se emplea hasta finales del siglo XII, con Sancho VI el Sabio (1132 - 1194). IBÁÑEZ ARTICA, Miguel, "Sustitución de la denominación de 'Reino de Pamplona' por 'Reino de Navarra' en el siglo XII. Motivaciones políticas y pruebas numismáticas", Numisma, 236, 1995, págs. 139-159.

47. Cf. por ejemplo CANTERA MONTENEGRO, Margarita, "Falsificación de documentación monástica en la Edad Media: Santa María de Nájera", Espacio, Tiempo y Forma, Serie III, Historia Medieval, t. 26, 2013, págs. 59-76.

48. Cf. por ejemplo FONTANA, Mario, Piedras preciosas, Barcelona, De Vecchi, 2007; HALL, Cally, Piedras preciosas: guía visual de más de 130 variedades de piedras preciosas, Barcelona, Ediciones Omega, 2006; WEBSTER, Robert, Piedras preciosas. Sus fuentes, descripciones e identificación, Barcelona, Ediciones Omega, 1987. 
Su utilización como pago del rescate redentor de Cristo en las Maiestas riojanas y también al pie de la Cruz de Sancho Abarca tiene por tanto pleno sentido simbólico, y coincide con los datos que aportan los cronistas sobre las huellas históricas riojanas de la espinela conocida como rubí del Príncipe Negro. No está claro de dónde pudo llegar el carbunclo de origen oriental a la posesión de Sancho Abarca, pero no necesariamente fue fruto de botín. Pudo haber sido también un intercambio de regalos con los gobernadores de Zaragoza o el Califa Abderramán III en tiempos de la reina Toda de Pamplona. El mismo Sancho Abarca fue abuelo del último caudillo militar de la Córdoba califal, el hijo de Almanzor conocido como el Sanchuelo. No solo había guerras en España en los albores del año $1000^{49}$.

Quizás futuros trabajos de investigación aporten más luz sobre la llegada a España del rubí de la Corona del Estado Imperial que adornaba simbólicamente la Cruz de Sancho Abarca que su biznieto García el de Nájera donó al monasterio de Santa María la Real en su fundación. Mientras esto se produce, es preciso constatar que el origen riojano del rubí del Príncipe Negro es una hipótesis con mucho más fundamento científico -basado tanto en pruebas iconográficas como en testimonios de cronistas y testigos- que la teoría granadina actualmente de moda.

\section{Bibliografía}

ANGHEBEN, Marcello, "Theophanies absidales et liturgie eucharistique. L'exemple des peintures romanes de Catalogne et du nord de Pyrenees comportant un seraphin et un cherubin”, GUARDIA, M. y MANCHO, C., Ars picta, Temes 1, Universidad de Barcelona, 2008, págs. 57-95.

ARRUE UGARTE, Begoña, "Cruces procesionales en La Rioja: aspectos tipológicos, siglos XIII al XVI", Cuadernos de Investigación Histórica, Brocar, n.o 14, 1988, págs. 119-155.

BUTLER, Thomas, The Crown Jewels and Coronation Ceremony, Pitkin, Antiques \& Collectibles, 1989.

CANTERA MONTENEGRO, Margarita, "Falsificación de documentación monástica en la Edad Media: Santa María de Nájera”, Espacio, Tiempo y Forma, Serie III, Historia Medieval, t. 26, 2013, págs. 59-76.

CANTERA MONTENEGRO, Margarita, "La devoción mariana en La Rioja medieval”, VV.AA., Devoción mariana y sociedad medieval, actas del simposio, Ciudad Real, Instituto de Estudios Manchegos, 1990, págs. 455-470.

CANTERA MONTENEGRO, Margarita, Santa María la Real de Nájera. Siglos XI-XIV, T. I-de 3- Madrid, Universidad Complutense, 1987.

CANTERA MONTENEGRO, Margarita, "Santa María la Real de Nájera en la Edad Media”, I Semana de Estudios Medievales, Nájera, del 6 al 11 de agosto de 1990, Logrońo, Instituto de Estudios Riojanos, Logrońo, 2001, págs. 207-230, https://dialnet.unirioja.es/descarga/articulo/595370.pdf, (consultado en mayo de 2017).

CANTERA ORIVE, Julián, Un cartulario de Santa María la Real de Nájera del año 1209, Biblioteca Gonzalo de Berceo, n. ${ }^{\circ}$ 55, págs. 331-346,

http://www.vallenajerilla.com/berceo/canteraorive/cartulariosantamarialarealdenajera.htm, (consultado en mayo de 2017).

Códice Vigiliano o Albedense, Biblioteca Gonzalo de Berceo, http://www.vallenajerilla.com/albeldense/index. htm, (consultado en mayo de 2017).

\footnotetext{
49. Aunque son fechas posteriores a la elaboración de los códices riojanos, Sancho ll entregó a su hija como esposa a Almanzor en 982 , como prenda tras la derrota de Rueda, sufrida también por los reyes de Asturias-León. Después de dar a luz al Sanchuelo, Urraca recibió permiso para ingresar en un convento, y Almanzor se lo concedió. Almanzor emprendió su primera campaña contra el reino de Pamplona-Nájera en 992, y saqueó San Millán y otros monasterios. Como por las armas no se podía con Almanzor, el 4 de septiembre de 992, Sancho Garcés acudió a Córdoba como embajador de su propio reino llevando cuantiosos regalos para el victorioso Almanzor y pactando con él la no agresión. Su hijo Gonzalo volvió en 993 para dar seguridades a Córdoba de esta actitud de sumisión. Y, sin embargo, quizás por esta especial protección que gozó del mismo Almanzor, Sancho II, identificado con Abarca solo a partir del siglo XVI, fue el monarca más relevante de los reyes y príncipes cristianos del momento. MARTíNEZ DÍEZ, Gonzalo, El Condado de Castilla (711-1038). La historia frente a la leyenda, Valladolid, Junta de Castilla y León, tomo II, 2005, pág. 525; y así lo reflejaban también las artes.
}

atrio n. $^{\circ}{ }_{24} \mid 2018$ 
COOK, Walter William Spencer, “The Earliest Painted Panels of Catalonia (II)”, Art Bulletin, VI, 1923, págs. 152-204.

FERNÁNDEZ GONZÁLEZ, Etelvina, Imágenes del poder en la Edad Media. Estudios in memoriam del prof. Fernando Galván Freile. Tomo II. León, Universidad de León, 2011.

FERNÁNDEZ GONZÁLEZ, Etelvina y GALVÁN FREILE, Fernando, "Iconografía, ornamentación y valor simbólico de la imagen”, Códice Albeldense, 976, Colección Scriptorium, 15, 2002, págs. 205-277.

FITA, Fidel, "Santa María la Real de Nájera. Estudio Crítico”, Boletín de la Real Academia de la Historia, 1885, págs. 156-198.

FONTANA, Mario, Piedras preciosas, Barcelona, De Vecchi, 2007.

GALVÁN FREILE, Fernando, Imágenes del poder en la Edad Media. Selección de estudios del prof. Fernando Galván Freile. Tomo I. León, Universidad de León, 2011.

GARRÁN, Constantino, "El Becerro de Santa María la Real de Nájera”, Boletín de la Real Academia de la Historia, Tomo 49, 1906, págs. 385-389.

GARRÁN, Constantino, Santa María la Real de Nájera. Memoria histórico-descriptiva, Logroño, Establecimiento Tipográfico de La Rioja, 1892.

GIL FERNÁNDEZ, Juan; MORALEJO, José Luis y RUIZ DE LA PEÑA SOLAR, Juan Ignacio, Crónicas asturianas, Oviedo, Universidad de Oviedo (Publicaciones del Departamento de Historia Medieval, 11), 1985.

HALL, Cally, Piedras preciosas: guia visual de más de 130 variedades de piedras preciosas, Barcelona, Ediciones Omega, 2006.

IBÁÑEZ ARTICA, Miguel, “Sustitución de la denominación de 'Reino de Pamplona’ por 'Reino de Navarra’ en el siglo XII. Motivaciones políticas y pruebas numismáticas”, Numisma, 236, 1995, págs. 139-159.

ISLA FREZ, Amancio, "Identidades y goticismo en época de Alfonso III: las propuestas de la Albeldense", Territorio, Sociedad y Poder, n. ${ }^{\circ}$ 6, 2011, págs. 11-21.

JOVELLANOS, Gaspar Melchor de, Obras Completas, Madrid, B.AA.EE. 1956, volumen III.

JUSUÉ SIMONENNA, Carmen y RAMÍREZ VAQUERO, Eloísa, La moneda en Navarra, Pamplona, Gobierno de Navarra, 2002.

KEAY, Anna, The Crown Jewels: The Official Illustrated History, London, Thames \& Hudson. 2011.

KESSLER, Herbert L., The Illustrated Bibles from Tours, Princeton N. J. Princeton University Press, 1977.

KUME, Junko, "Aspectos de la influencia iconográfica carolingia en la miniatura hispánica de los siglo X y XI”, CABAÑAS BRAVO, M. (edit.), El arte foráneo en España: presencia e influencia, Madrid, CSIC, 2005, págs. 207-214.

LÓPEZ DE AYALA, Pedro, Crónica del rey don Pedro, año III, 1362, cap. V. en Imprenta de don Antonio de Sancha, Crónicas de los reyes Castilla, I: Crónica del rey don Pedro, Madrid, 1779.

MADRAZO, Pedro de, Navarra y Logroño, en España, sus Monumentos y Artes - Su Naturaleza e Historia, Barcelona, 1886.

MARTÍNEZ DÍEZ, Gonzalo, El Condado de Castilla (711-1038). La historia frente a la leyenda, Valladolid, Junta de Castilla y León, tomo II, 2005.

MEER, Frederick van der, Maiestas Domini, Roma, Città del Vaticano, 1938.

MENÉNDEZ PIDAL, Gonzalo, "El lábaro primitivo de la reconquista", Varia Medievalia I, Madrid, Real Academia de la Historia, 2003, págs. 177-202.

MORET, José, Investigaciones Historicas De Las Antiguedades Del Reyno De Navarra, Por El Padre Joseph De Moret, De La Compañia De Jesús, 6, 1766 (tercera ed.), cap. VIII. 
MOYA VALGAÑÓN, Migué Ángel, El arte en la Rioja (I): La Edad Media, Logroño, Diputación de La Rioja, 1982.

ORPEN, Goddard, Stories about Famous Precious Stones, Boston, Lothrop, 1890.

REGLERO DE LA FUENTE, Carlos M., La Crónica najerense, Santa María de Nájera y Cluny, en E-Spania, 2009, http://e-spania.revues.org/18162, (consultado en mayo de 2017).

"Royal Collection Trust", https://www.royalcollection.org.uk/collection/31701/the-imperial-state-crown, (consultado en mayo de 2017).

SANDOVAL, Prudencio de, Catálogo de los obispos que ha tenido la Santa Iglesia de Pamplona, Pamplona, 1614.

SANDOVAL, Prudencio de, Primera parte de las fundaciones de los monasterios del glorioso Padre San Benito ... y de los santos ... varones desta sagrada religion, que desde el año DXL ... hasta el año DCCXIIII ... han florecido en estos monasterios ... Publicación original: En Madrid, por Luis Sánchez, 1601.

SCHAPIRO, Meyer, "Dos dibujos románicos de Auxerre y algunos problemas iconográficos”, VV. AA. Estudios sobre el románico, Madrid, Alianza Forma, 1984.

SILVA Y VERÁSTEGUI, Soledad de, Iconografía del siglo X en el reino de Pamplona-Nájera, Pamplona, Príncipe de Viana/Instituto de Estudios Riojanos, 1984, http://www.vallenajerilla.com/berceo/silvaverastegui/talleremilianense.htm (consultado en mayo de 2017). SILVA Y VERÁSTEGUI, Soledad de, “La miniatura en el Reino de Pamplona-Nájera (905-1076)”, IGLESIA, José Ignacio de la (coord.), García Sánchez III "el de Nájera" un rey y un reino en la Europa del siglo XI: XV Semana de Estudios Medievales, Nájera, Tricio y San Millán de la Cogolla, Logroño, Instituto de Estudios Riojanos, 2005, págs. 327-366.

SILVA Y VERÁSTEGUI, Soledad de, "Los primeros retratos reales en la miniatura hispánica altomedieval. Los monarcas de Pamplona y de Viguera”, Príncipe de Viana, Pamplona, 1980, págs. 257-261.

SÓLANS HUGUET, Joaquín, Gemas de ayer, de hoy y de mañana. Introducción al Estudio de las piedras preciosas, Barcelona, Edicions Universitat Barcelona, 1914.

STRATFORD, Jenny, Richard II and the English Royal Treasure, Suffolk, Boydell Press, 2012.

VERGAZ, Miguel Ángel, "La RAE avala que Burgos acoge las primeras palabras escritas en castellano”, $E l$ Mundo, 7 de noviembre de 2010, http://www.elmundo.es/elmundo/2010/11/07/castillayleon/1289123856.html (consultado en mayo de 2017).

WEBSTER, Robert, Piedras preciosas. Sus fuentes, descripciones e identificación, Barcelona, Ediciones Omega, 1987.

YEPES, Antonio de, Corónica General de la Orden de San Benito, Volumen 6, 1617. YEPES, Antonio de, Corónica General de la Orden de San Benito, Volumen 7, 1621. 